Journal of Money and Economy

Vol. 15, No. 1, Winter 2020

pp. $75-100$

DOI: $10.29252 /$ jme.15.1.75

Original Research Article

\title{
Iranian Banks Mergers and Structure of Loans
}

\begin{abstract}
Azam Ahmadyan*
Received: 5 Nov 2019

Approved: 28 Oct 2020

Iranian banking network policymakers are focused on bank consolidation as one of the reform policies in recent years. But before merging banks, it is necessary to examine their effects. Loans are one crucial item in the banks' balance sheets that are affected by bank consolidation. In the Iranian banking network, loans are offered to various economic sectors. What is important for banking policymakers is how the structure of loans will change as banks merge. Also, the effect of bank consolidation on loan structure is affected by the bank's ownership and its performance. Therefore, in this paper, we investigate the impact of bank mergers on loan structure of banks, using panel data model and financial statements of Iranian banks in 2006-2018. For this purpose, 28 models have been designed. Results indicate the merger of banks and the creation of private banks have a positive effect on the loan supply to services and the business sector. The merging of banks and the creation of state-owned banks will also have a positive impact on the loan supply to the industry and mining, construction, and housing sectors. Also, banks merger has a positive effect on the loan supply to services and the business sector.
\end{abstract}

Keywords: Bank Merger, Bank's Ownership, Healthy Bank, Structure of Loans. JEL Classification: C21, G21, G34

\section{Introduction}

Bank mergers have some potential effects on borrowers, either benefit or harm. On the one hand, mergers may generate efficiency gains - cost savings, revenue-enhancing. Also, greater bank size can yield economies of scale and scope and increasing diversification opportunities. Borrowers will benefit to the extent that consolidated banks pass on efficiency gains to them. On the other hand, bank consolidation may increase market concentration. Borrowers will be harmed to the extent that consolidated banks exert their market power (Montoriol-Garriga, 2008). Mergers can increase, the efficiency of banks through direct synergies, re-optimization of the loan portfolios, and risk diversification (Farrell \& Shapiro, 1990).

\footnotetext{
* Assistant Prof, Faculty in Banking Department, Monetary and Banking Research Institute, Tehran, Iran; azam_ahmadyan@yahoo.com
} 
In Iran, bank loans are received by different economic sectors: Agriculture, Industry and Mining, Services and Business, Export, Construction, and Housing. Activists in different economic sectors need to know to what extent the bank loans will be affected by bank merger. In this paper, considering the importance of the issue of sensitivity of loans to bank mergers, the effect of bank merger on the combination of loan has been examined using the financial statements of Iranian banks in 2006-2018 published annually by the Iran Banking Institute.

Since the new wave of bank mergers in Iran has begun in 2018, and no empirical data concerning such development is out yet, a simple method of merging banks has been used. In this method, the financial statements of banks are simply combined. So merged bank asset is the sum of the assets of the two merged banks. In Iran, banks are divided into several groups, such as commercial state banks, specialized state banks, commercial private banks, commercial privatized banks (banks that were formerly government-owned and are now private), and Qarz Al-Hasaneh banks.

In this paper, privatized and Qarz Al-Hasaneh banks are grouped with private banks based on their ownership structure. Then, in this paper, banks are divided into three groups, according to the type of ownership, commercial state bank, specialized state bank, private bank.

One of the most critical factors affecting the effects of bank mergers is the stability and health of banks. For this reason, in this paper, using the CAMELS rating method, banks are divided into two groups; healthy and unhealthy banks. What is important in this article is the answer to two questions. What combination of banks, by the type of ownership, has the most positive effect of the kind of economic sectors that received loans? Which loans are more affected by bank mergers?

To answer these two questions, 28 models were designed, and 30 hypotheses were tested.

This article considers some points that distinguish it from other studies.

1) In this study, banks are divided by type of ownership and health, which is a missing link in empirical studies.

2) We used a T-test to answer this question as to which ownership has had the most positive effect on the supply of loans.

3) In this study, we used the Equality Test of Coefficients (T-statistic) to determine which of the various loans are affected by bank mergers.

4) This study examines the effect of bank mergers on the supply of loans in various economic sectors such as Agriculture, Export, Industry and Mining, Construction and Housing, Services and Business. Other 
empirical studies, however, have focused solely on the Agricultural or Business sectors.

The remainder of this paper is organized as follows: The second section survey literature review about the effect of banks merger on the structure of loans. Section three describes the empirical methodology, validates our methodology, descriptive statistics, and the results of unit root and panel data tests. Section four presents the research findings and hypostatized tests. Section five indicates a conclusion. The tables in the appendix indicate model output.

\section{Literature Review}

In international studies, few studies have examined the effect of bank mergers on the composition and structure of loans, and most studies have focused on exploring the effect of bank mergers on the supply of loans to one or two sectors of the economy. This group of studies has not examined which types of loans are most affected by bank mergers. They also ignored banks' ownership and healthiness. There has been no study in this field in Iran. In this section, we study some of the international studies in this field.

Some studies such as Kahn, Pennacchi, and Sopranzetti (2005), examine effect of banks mergers on loans interest rate. Results suggest bank mergers have negative influence on automobile interest rate but no any effect o personal loans interest rates.

Other studies such as Strahan and Weston (1998), Avery and Samolyk (2004), examine the effect of merger between small banks on structure of loans. They found that merger between small banks tend to increase loans supply to small borrowers and small business. In contrast other studies such as Gilbert and Belongia (1988), Keeton (1996), Peek and Rosengren (1998), Ahrendsen, Dixon, and Luo (2003), by examining this issues, they found different results from Strahan and Weston (1998), Avery and Samolyk (2004). They found consolidation between small banks tend to reduce supply of loans to small business such as agriculture. Other studies such as Berger et al. (2004), Erel (2011), Berger, Rosen, and Udell (2007), and Di Patti and Gobbi (2007), examine the effect of merger and acquisition on reallocation portfolio. They found, loan portfolio changes after merger and loan to big business increase but loan to small business decrease.

\section{Methodology}

In this section, the effect of bank consolidation on the composition of loans is examined using the financial statements of 28 banks in 2006-2018. Since 
banks' ownership and health status affect the result of bank consolidation, in this paper, banks are divided in terms of ownership and health. Then the banks have been merged in terms of their type of ownership and health. In terms of bank ownership, they are divided into three groups: commercial state banks, specialized state banks, private banks, and in terms of health, they are also divided into two groups of healthy and unhealthy banks. Since the integration of banks in Iran has started from 2018, there is no real consolidated financial statement, so in this paper, financial statements are simply combined, as the new bank's financial statements are derived from the sum of the two banks' financial statements.

To select banks to simulate mergers in terms of ownership, it has been attempted to identify the largest and smallest banks in terms of size, and then compare the largest bank in one group with the smallest bank in the other. This method is chosen because too big to fail is not considered or will not happen. The banks' rating method was used to divide banks into two groups of healthy and unhealthy banks, through the banks have been ranked 1 and 5 to select banks for merging. To create a merged bank, the financial statements of the banks are simply combined. After grouping the banks, a unit root test has been performed to ensure that the unit root does not exist. Also, using the F-Limer and Husman test, an appropriate model is selected.

The structure of this section is as follows:

1) Grouping banks by type of ownership and health

2) Banks' ratings based on the CAMELS method

3) Introducing the investigated models

4) Applying unit root test

5) Selection method of panel data regression

\subsection{Grouping Banks by Type of Ownership and Health}

The composition of banks by type of ownership and health is shown in Table 1.

Table 1

Composition of banks by type of ownership and health

\begin{tabular}{ll}
\hline Healthy & Ownership \\
\hline Healthy - Unhealthy & Commercial State - Commercial State \\
Unhealthy- Unhealthy & Commercial State- Commercial Private \\
Healthy - Healthy & Commercial Private - Commercial Private \\
& Specialized State - Commercial Private \\
\hline
\end{tabular}


The combination of loans in the Iranian banking network includes Agricultural, Export, Service, Business, Industrial and Mining, Construction, and Housing loans. The share of Agricultural and Export Loans to total loans is less than $2 \%$ of total banking loans. Agricultural and Export Loans are considered under one heading. Some of the banks' Services and Business Loans are not separated and are presented under one headline of service sector loans.

\subsection{Banks' Ratings Based on the CAMELS Method}

The CAMELS ranking method is as follows:

We have identified safe banks using the CAMELS method. CAMELS' indicators are introduced in table 2. The United States first introduced the criteria in 1979, and the IMF introduced its updated version in 1996.

Table 2

CAMELS Indicators

\begin{tabular}{|c|c|c|}
\hline CAMEL & Ratios & Formula \\
\hline \multirow[t]{3}{*}{ Capital Adequacy } & Capital Adequacy Ratio & $\begin{array}{lll}(\text { (Tier } & 1 & \text { Capital }\end{array}$ \\
\hline & & $\begin{array}{l}\text { Goodwill)+Tier } 2 \text { Capital)/ Risk } \\
\text { Weighted Assets }\end{array}$ \\
\hline & Equity Capital to Total Assets & Total Capital /Total Assets \\
\hline \multirow[t]{4}{*}{ Asset Quality } & NPLs to Total Loans & NPLs/Total Loans \\
\hline & NPLs to Total Equity & NPLs/Total Equity \\
\hline & $\begin{array}{l}\text { Allowance for Loan Loss } \\
\text { Ratio }\end{array}$ & $\begin{array}{l}\text { Allowance for Loan Loss / } \\
\text { Total Loans }\end{array}$ \\
\hline & Provision for Loan Loss Ratio & $\begin{array}{l}\text { Provision for Loan Loss/ Total } \\
\text { Loans }\end{array}$ \\
\hline \multirow[t]{3}{*}{ Management Quality } & Total Asset Growth Rate & $\begin{array}{l}\text { Average of Historical Asset } \\
\text { Growth Rate }\end{array}$ \\
\hline & Loan Growth Rate & $\begin{array}{l}\text { Average of Historical Loan } \\
\text { Growth Rate }\end{array}$ \\
\hline & Earnings Growth Rate & $\begin{array}{l}\text { Average of Historical Earning } \\
\text { Growth Rate }\end{array}$ \\
\hline Earning Ability & Cost to Income Ratio & $\begin{array}{l}\text { Operational Expence(Excludes } \\
\text { Provision Loss)/( Net Interest } \\
\text { Income + Non Interest Income }\end{array}$ \\
\hline Sensitivity to Risk & Sensitivity to Market Risk & $\begin{array}{llll}\begin{array}{l}\text { Currency } \\
\text { Capital }\end{array} & \text { Open Position to } \\
\end{array}$ \\
\hline
\end{tabular}

We calculate the measure of the combined CAMELS ratio. First, each CAMELS ratio is normalized using the minimum and maximum ratios. 
$\left(\frac{a_{i}-L}{U-L}\right)$

Where $\mathrm{L}$ and $\mathrm{U}$ are, minimum and maximum of CAMELS ratio. Then, to derive an indicator for the combined CAMELS, the sum of these normalized indices is calculated.

$$
C s_{i}=\sum\left(\frac{a_{i}-L}{U-L}\right)
$$

Where CSi is Combined CAMELS ratios. CSi is between zero and one. Zero is the worst situation, and one is the best situation in this criterion (Prasad \& Ravinder, 2012). Table 3 shows ranking.

Table 3

Ranking

\begin{tabular}{cc}
\hline Rank & Criterion \\
\hline 1 & $0.8<C S_{i}<1$ \\
2 & $0.6<C S_{i}<0.8$ \\
3 & $0.4<C S_{i}<0.6$ \\
4 & $0.2<C S_{i}<0.4$ \\
5 & $0<C S_{i}<0.2$ \\
\hline
\end{tabular}

Banks that are ranked 1 and 2, banks have good health. If the rank of banks is 3 , these banks are medium health and banks with 4 and 5 ratings, these banks are high risk and have poor health.

\subsection{Introducing the Investigated Models}

In this paper, two fundamental questions are answered, what combination of banks, by the type of ownership, has the most positive effect of the kind of economic sector loan offered? What type of loan is more affected than others? To answer these questions, 28 models are estimated, and thirty hypotheses have been tested. The models are presented in the following table. 
Table 4

Models

\begin{tabular}{|c|c|c|c|c|c|c|c|}
\hline \multicolumn{2}{|l|}{$\begin{array}{c}\text { Banking } \\
\text { Grouping }\end{array}$} & \multicolumn{2}{|c|}{ Soundness } & \multicolumn{4}{|c|}{ Ownership } \\
\hline Loan & Healthy- & Healthy & Unhealthy & Commercial & Commercial & Commercial & Specializes \\
\hline Composition & Healthy & Unhealthy & Unhealthy & $\begin{array}{l}\text { State Bank- } \\
\text { Commercial } \\
\text { State Bank }\end{array}$ & $\begin{array}{l}\text { State Bank - } \\
\text { Commercial } \\
\text { Private Bank }\end{array}$ & $\begin{array}{l}\text { Private } \\
\text { Bank- } \\
\text { Commercial } \\
\text { Private Bank }\end{array}$ & $\begin{array}{l}\text { State Bank- } \\
\text { Commercial } \\
\text { Private } \\
\text { Bank }\end{array}$ \\
\hline $\begin{array}{l}\text { Agriculture } \\
\text { and Export }\end{array}$ & Model1 & Model2 & Model3 & Model4 & Model5 & Model6 & Model7 \\
\hline $\begin{array}{l}\text { Services and } \\
\text { Business }\end{array}$ & Model8 & Model9 & Model10 & Model11 & Model12 & Model13 & Model14 \\
\hline $\begin{array}{l}\text { Manufacturing } \\
\text { and Mining }\end{array}$ & Model15 & Model16 & Model17 & Model18 & Model19 & Model20 & Model21 \\
\hline $\begin{array}{l}\text { Construction } \\
\text { and Housing }\end{array}$ & Model22 & Model23 & Model24 & Model25 & Model26 & Model27 & Model28 \\
\hline
\end{tabular}

\subsection{Unit Root Test}

The results of the unit root test are shown in Table 5. For the unit root test, four statistics, PP-Fisher, ADF- Fisher, Im, Pesaran and Shin W-Stat, Levin, Lin and Chu were used. The results show that the variables used are stationary at the level and Inference and significance at the level of 5\%. 
Table 5

Unit root test

\begin{tabular}{|c|c|c|c|}
\hline $\begin{array}{l}\text { PP-Fischer Chi- } \\
\text { Square }\end{array}$ & $\begin{array}{l}\text { ADF-Fisher Chi- } \\
\text { Square }\end{array}$ & $\begin{array}{l}\text { Im, Pesaran \& } \\
\text { Shin W-stat }\end{array}$ & $\begin{array}{l}\text { Levin, Lin \& Chu } \\
\mathrm{t}\end{array}$ \\
\hline $\begin{array}{ll}\text { Agriculture } & +118.147 \\
\text { Export Loan) } & \text { to }(0.000) \\
\text { Total Loan } & \end{array}$ & $\begin{array}{l}128.017 \\
(0.000)\end{array}$ & $\begin{array}{l}-10.0528 \\
(0.000)\end{array}$ & $\begin{array}{l}-29.5959 \\
(0.0000)\end{array}$ \\
\hline $\begin{array}{l}\text { (Service }+151.168 \\
\text { Business Loan) to }(0.000) \\
\text { Total Loan }\end{array}$ & $\begin{array}{l}130.560 \\
(0.000)\end{array}$ & $\begin{array}{l}-13.2239 \\
(0.000)\end{array}$ & $\begin{array}{l}-56.8709 \\
(0.000)\end{array}$ \\
\hline $\begin{array}{l}\text { Industry and } 80.7614 \\
\text { Mining Loan to }(0.0038) \\
\text { Total Loan }\end{array}$ & $\begin{array}{l}71.2142 \\
(0.0260)\end{array}$ & $\begin{array}{l}-5.56464 \\
(0.000)\end{array}$ & $\begin{array}{l}-32.0380 \\
(0.000)\end{array}$ \\
\hline $\begin{array}{l}\text { Construction and } 109.420 \\
\text { Housing Loan to }(0.000) \\
\text { Total Loan }\end{array}$ & $\begin{array}{l}101.335 \\
(0.0001)\end{array}$ & $\begin{array}{l}-6.33102 \\
(0.0000)\end{array}$ & $\begin{array}{l}-23.9069 \\
(0.0000)\end{array}$ \\
\hline $\begin{array}{ll}\text { Deposit } & 170.431 \\
& (0.000)\end{array}$ & $\begin{array}{l}134.455 \\
(0.000)\end{array}$ & $\begin{array}{l}-6.76924 \\
(0.000)\end{array}$ & $\begin{array}{l}-15.6141 \\
(0.000)\end{array}$ \\
\hline $\begin{array}{l}\text { Non-Performing } 136.791 \\
\text { Loan to Total }(0.000) \\
\text { Loan }\end{array}$ & $\begin{array}{l}128.961 \\
(0.000)\end{array}$ & $\begin{array}{l}-6.77878 \\
(0.000)\end{array}$ & $\begin{array}{l}-15.9265 \\
(0.000)\end{array}$ \\
\hline $\begin{array}{ll}\text { Liquid Assets to } 123.225 \\
\text { Short Term Debt }(0.000) \\
\text { Capital Adequacy } 145.968 \\
\\
(0.000)\end{array}$ & $\begin{array}{l}112.385 \\
(0.000) \\
120.722 \\
(0.000) \\
\end{array}$ & $\begin{array}{l}-55.5154 \\
(0.000) \\
-5.48640 \\
(0.000)\end{array}$ & $\begin{array}{l}-96.0812 \\
(0.000) \\
-18.2569 \\
(0.000) \\
\end{array}$ \\
\hline
\end{tabular}

\subsection{Selection Method of Panel Data Regression}

Various tests are used to determine the type of Panel Data model. The most general test is the F-Limer test for using the fixed effects model against the estimated model of Pooled Data. Consider the following model:

$Y_{i t}=\alpha_{i}+\beta X_{i t}+\mu_{i}+\cdots .+v_{i t}$

The disturbance term, $v_{i t}$, has a normal distribution and all i's and t's are independent of $X_{i t}$ and are not correlated with it [12]. So, what must be checked first to see whether there are heterogeneity or individual differences. If there is heterogeneity, the panel data approach will be used; otherwise, the ordinary least squares (OLS) models are used to estimate the model. The $\mu_{i} ; \mathrm{s}$ represents the individual effects or heterogeneity in the cross-sections and appears in the form of random effects or fixed effects. Comparison of the panel data method with the ordinary least squares method is evaluated in the framework of the following hypothesis: 
$H_{0}=\mu_{1}=\mu_{2}=\mu_{3}=\cdots=\mu_{N}=0$

$H_{1}=$ At least one of the $u_{i}^{\prime}$ sis non zero.

To test the above hypothesis, the F-Limer statistic is used (Baltagi (2005)).

Table 6 provides the calculated statistical value for the F-Limer test. The numbers in parentheses are p-value. According to this Table, we can use the Panel Data method to estimate the model.

Table 6

F-Limer Test

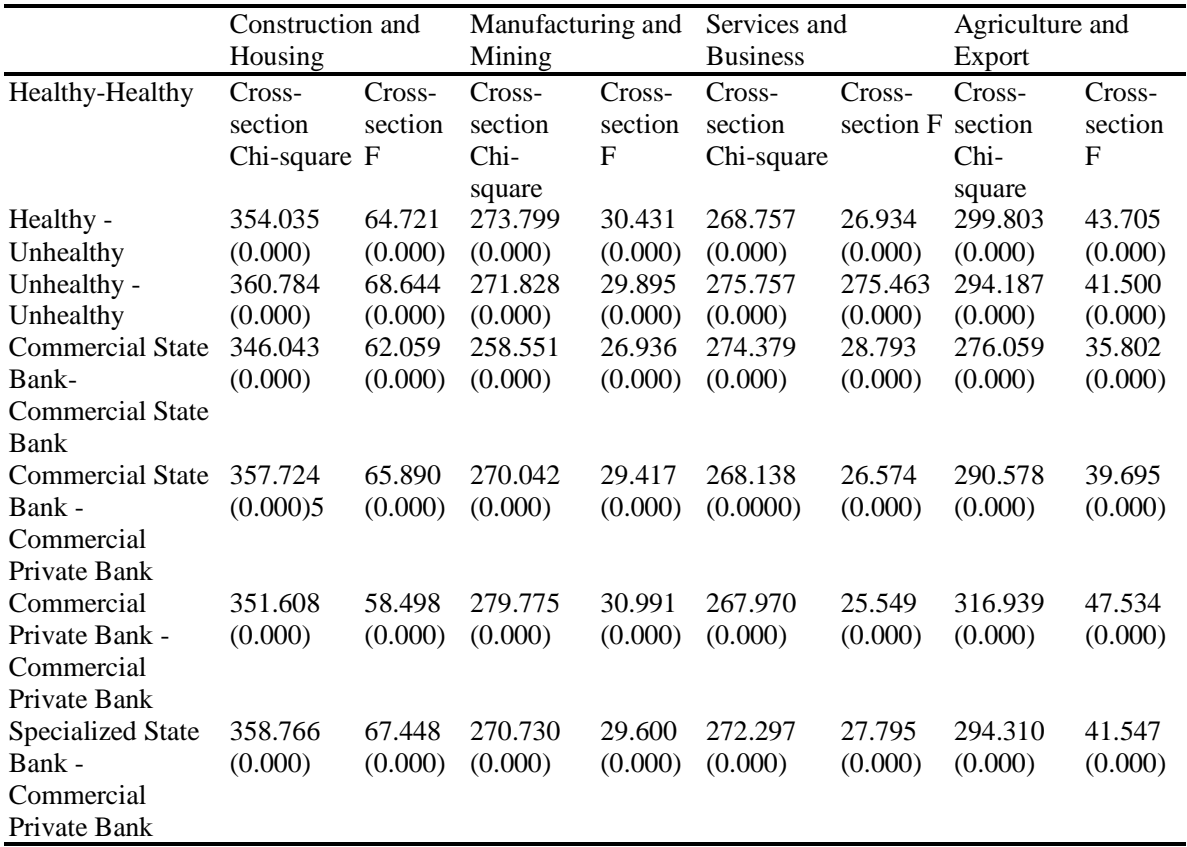

Hausman (1978) Test is used for choosing between the fixed effects model and the random effects model. The statistic of this test $(\mathrm{H})$ has a chi-squared distribution with $\mathrm{k}$ (the number of explanatory variables) degrees of freedom. Given that an important assumption about the disturbance components of the regression model is that $\mathrm{E}\left(\mathrm{U}_{\mathrm{it}} \mid \mathrm{X}_{\mathrm{it}}\right)$, that is the same assumption of the independence of disturbance components from the explanatory variables, Hausman suggests that both effects be compared under the null $\mathrm{H}_{0}: \mathrm{E}\left(\mathrm{U}_{\mathrm{it}} \mid \mathrm{X}_{\mathrm{it}}\right)=0$. The random effect estimator is consistent and 
asymptotically efficient just if the null hypothesis is not rejected. In contrast, the fixed effects estimator is consistent whether the null be rejected or not (Haddad \& Mohit, 2012).

As Table 7 shows, based on the calculated probability value for the Hausman test, we find out that the Fixed effects model must be used to estimate the model because the p-value is less than 0.05 . The numbers in parentheses are p-value.

Table 7

Hausman Test

\begin{tabular}{lllll}
\hline $\begin{array}{l}\text { Kind of Bank } \\
\text { Merging }\end{array}$ & $\begin{array}{l}\text { Construction } \\
\text { and Housing }\end{array}$ & $\begin{array}{l}\text { Manufacturing } \\
\text { and Mining }\end{array}$ & $\begin{array}{l}\text { Services and } \\
\text { Business }\end{array}$ & $\begin{array}{l}\text { Agriculture } \\
\text { and Export }\end{array}$ \\
\hline Healthy-Healthy & 36.710 & 43.353 & 38.963 & 6.872 \\
& $(0.000)$ & $(0.000)$ & $(0.000)$ & $(0.550)$ \\
Healthy - Unhealthy & 39.195 & 34.255 & 49.091 & 4.804 \\
& $(0.000)$ & $(0.000)$ & $(0.000)$ & $(0.778)$ \\
Unhealthy - Unhealthy & 46.614 & 41.284 & 45.375 & 5.397 \\
& $(0.000)$ & $(0.000)$ & $(0.000)$ & $(0.714)$ \\
Commercial State & 40.294 & 35.331 & 35.466 & 4.875 \\
Bank- Commercial & $(0.000)$ & $(0.000)$ & $(0.000)$ & $(0.770)$ \\
State Bank & & & & \\
Commercial State & 44.323 & 64.964 & 33.723 & 4.918 \\
Bank - Commercial & $(0.000)$ & $(0.000)$ & $(0.000)$ & $(0.766)$ \\
Private Bank & & & & \\
Commercial Private & 36.690 & 34.065 & 46.632 & 7.393 \\
Bank - Commercial & $(0.000)$ & $(0.000)$ & $(0.000)$ & $(0.494)$ \\
$\begin{array}{l}\text { Private Bank } \\
\text { Specialized State Bank }\end{array}$ & 41.211 & 44.212 & 43.867 & 5.296 \\
- Commercial Private & $(0.000)$ & $(0.000)$ & $(0.000)$ & $(0.725)$ \\
Bank & & & & \\
\hline
\end{tabular}

\section{Research Finding and Hypothesis Test}

The results of the model estimation are presented in Tables 10-17 (see appendix). The numbers in () the statistics $t$ and the numbers inside [] are probabilities. To select independent variables, we used previous experiences in identifying the factors affecting the structure of loans and selecting repeat variables as independent final variables. This section analyses the effect of banks' mergers on the supply of loans, regardless of the type of ownership, health, and loans.

As can be seen, the ratio of non-performing loans to total loans, liquid assets to short-term debts and capital adequacy have negative relationships 
with loans. As the proportion of non-performing loans increases, the banks' blocked resources will increase in the economy, and banks will be deprived of the resources available for loans. It will reduce the supply of loans. On the other hand, an increase in the ratio of liquid assets to short-term debts indicates that the bank has taken a risk-taking approach, thereby reducing the profitability of the bank while decreasing its supply of loans. Capital adequacy is one of the banking health variables that banks are obligated to follow by $8 \%$. In Iran, according to the capital adequacy guidelines, banks are required to comply with the threshold of $8 \%$. Adhering to this principle will make banks block their resources to increase capital, so banks' supply of loans will be reduced. However, in the long run, maintaining the health and stability of the bank, the supply of loans will also increase. The size of the deposit has a positive and significant effect on the supply of loans. Capital adequacy has no significant effect on loans in Industry and Mining sector, Services, and Business sector. Also, liquid assets to short-term debts have no significant effect on loans in Agriculture and Export sector.

Effect of merging on the supply of loans based on Healthy, the combination of healthy and unhealthy banks reduces the supply of loans in the current period and then increases after one period. Because unhealthy banks are more vulnerable to credit risk and liquidity risk compared to healthy banks, this is the reason why, at the beginning of the merger, healthy banks focus on addressing the risks of the bank, and in the following years, they seek to attract customers and increase the supply of loans. The combination of unhealthy banks also has a negative effect on the supply of loans and contrasts with the Central Bank's goal of improving financing.

Three types of virtual variables have been used to investigate the effect of banks merging on the loans. A virtual variable is related to the merger in the current period that takes one number if it is merged in the current period. Otherwise, it will take a zero number. The second virtual variable is related to one period after the merger, which is for one period after the merge. The number is one, and otherwise, the number is zero. The third virtual variable is defined for two periods after the merger, which is for the two periods after the integration of the number is one, and otherwise, the number is zero.

Similarly, mergers in the current period do not have a significant effect on the supply of Loans. Because in the current period and after the merger, banks are still structuring the new bank and restructuring the financial and operational. Therefore, there is not much change in the supply of loans. But after two periods, due to the stability of the banking network, and increased 
customer confidence and continued relationships between customers and the new bank, loans will increase.

The effect of bank mergers on agricultural and Export sectors in terms of health and ownership type of banks indicates that bank mergers until the third period did not have a significant effect on the supply of loans in this sector. As banks merge and size of banks increase, they increase their supply of Services to Businesses loans more than other sectors because these sectors have higher returns than other sectors of the economy. Unhealthy banks are risk-averse, and the risk of Agriculture and Export is lower than others, as banks merge, they increase their facilities to this sector. Bank mergers, on the other hand, have no significant effect on the supply of facilities to the Mining and Industrial sector. Because it is an important part of the Iranian economy, banks are required to provide facilities in any case. Bank mergers have a significant and positive effect on Construction and Housing loans. This sector is one of the early returns and high returns sectors where the increasing supply of facilities to these sectors improves the profitability of banks.

The following hypothesis tests are used to answer the two questions in this article. The first question is which combination of banks, by the type of ownership, has the most positive effect of the kind of economic sector loan offered? The following assumptions are tested:

Hypothesis 1: A combination of banks based on model 4 has a more positive effect on the Agriculture and Export loan compared with model 5.

Hypothesis 2: A combination of banks based on model 4 has a more positive effect on the Agriculture and Export loan compared with model 6.

Hypothesis 3: A combination of banks based on model 4 has a more positive effect on the Agriculture and Export loan compared with model 7.

Hypothesis 4: A combination of banks based on model 5 has a more positive effect on the Agriculture and Export loan compared with model 6.

Hypothesis 5: A combination of banks based on model 5 has a more positive effect on the Agriculture and Export loan compared with model 7.

Hypothesis 6: A combination of banks based on model 6 has a more positive effect on the Agriculture and Export loan compared with model 7.

Hypothesis 7: A combination of banks based on model 11 has a more positive effect on the services loan compared with model 12.

Hypothesis 8: A combination of banks based on model 11 has a more positive effect on the services loan compared with model 13.

Hypothesis 9: A combination of banks based on model 11 has a more positive effect on the services loan compared with model 14. 
Hypothesis 10: A combination of banks based on model 12 has a more positive effect on the services loan compared with model 13.

Hypothesis 11: A combination of banks based on model 12 has a more positive effect on the services loan compared with model 14.

Hypothesis 12: A combination of banks based on model 13 has a more positive effect on the services loan compared with model 14.

Hypothesis 13: A combination of banks based on model 18 has a more positive effect on the Manufacturing and Mining loan compared with model 19.

Hypothesis 14: A combination of banks based on model 18 has a more positive effect on the Manufacturing and Mining loan compared with model 20.

Hypothesis 15: A combination of banks based on model 18 has a more positive effect on the Manufacturing and Mining loan compared with model 21.

Hypothesis 16: A combination of banks based on model 19 has a more positive effect on the Manufacturing and Mining loan compared with model 20.

Hypothesis 17: A combination of banks based on model 19 has a more positive effect on the Manufacturing and Mining loan compared with model 21.

Hypothesis 18: A combination of banks based on model 20 has a more positive effect on the Manufacturing and Mining loan compared with model 21. Hypothesis 19: A combination of banks based on model 25 has a more positive effect on the Construction and Housing loan compared with model 26.

Hypothesis 20: A combination of banks based on model 25 has a more positive effect on the Construction and Housing loan compared with model 27.

Hypothesis 21: A combination of banks based on model 25 has a more positive effect on the Construction and Housing loan compared with model 28.

Hypothesis 22: A combination of banks based on model 26 has a more positive effect on the Construction and Housing loan compared with model 27.

Hypothesis 23: A combination of banks based on model 26 has a more positive effect on the Construction and Housing loan compared with model 28.

Hypothesis 24: A combination of banks based on model 27 has a more positive effect on the Construction and Housing loan compared with model 28.

Table 8 indicates the results of the hypothesis tests. 
Table 8

Equivalent equality test (a combination of banks by ownership type)

\begin{tabular}{llll}
\hline Hypothesis & T- statistic & Prob & Results \\
\hline Hypothesis (1) & 0.350955 & 0.2052 & The Null hypothesis is not rejected \\
Hypothesis (2) & 0.135070 & 0.1783 & The Null hypothesis is not rejected \\
Hypothesis (3) & 0.664753 & 0.0078 & The Null hypothesis is rejected \\
Hypothesis (4) & 0.441384 & 0.2126 & The Null hypothesis is not rejected \\
Hypothesis(5) & 0.686656 & 0.0078 & The Null hypothesis is rejected \\
Hypothesis (6) & 0.406227 & 0.0021 & The Null hypothesis is rejected \\
Hypothesis (7) & 0.666512 & 0.0000 & The Null hypothesis is rejected \\
Hypothesis (8) & 0.102230 & 0.0000 & The Null hypothesis is rejected \\
Hypothesis (9) & 0.617787 & 0.8479 & The Null hypothesis is not rejected \\
Hypothesis (10) & 0.584818 & 0.0006 & The Null hypothesis is rejected \\
Hypothesis (11) & 0.687169 & 0.5844 & The Null hypothesis is not rejected \\
Hypothesis (12) & 0.731815 & 0.3304 & The Null hypothesis is not rejected \\
Hypothesize (13) & 0.411996 & 0.6381 & The Null hypothesis is not rejected \\
Hypothesis (14) & 0.555075 & 0.0015 & The Null hypothesis is rejected \\
Hypothesis (15) & 0.851806 & 0.0000 & The Null hypothesis is rejected \\
Hypothesis (16) & 0.237516 & 0.0088 & The Null hypothesis is rejected \\
Hypothesis (17) & 0.413546 & 0.0495 & The Null hypothesis is rejected \\
Hypothesis (18) & 0.621657 & 0.0002 & The Null hypothesis is rejected \\
Hypothesis (19) & 0.586446 & 0.8029 & The Null hypothesis is not rejected \\
Hypothesis (20) & 0.431067 & 0.8209 & The Null hypothesis is not rejected \\
Hypothesis (21) & 0.248012 & 0.0000 & The Null hypothesis is rejected \\
Hypothesis (22) & 0.938145 & 0.3175 & The Null hypothesis is not rejected \\
Hypothesis (23) & 0.156844 & 0.0000 & The Null hypothesis is rejected \\
Hypothesis (24) & 0.115152 & 0.0000 & The Null hypothesis is rejected \\
\hline
\end{tabular}

As can be seen, the combination of state-owned banks with different ownership banks has a more positive effect on the supply of Agricultural and Export facilities. It is because this group of banks is more exposed to government assignment facilities than others. But the combination of Private banks with other banks has a more positive effect on the loan supply to Services and Business sector. Also, since the two sectors of Industry and Mining, Construction and Housing, are more susceptible to macroeconomic fluctuations than other sectors of the economy, private banks, compared with commercial and specialized banks, are less likely to offer facilities to these sectors. Government-structured banks (commercial state and specialized state) are required to comply with government obligations. Therefore, even in adverse economic conditions, they have to increase the supply of facilities to 
these two sectors. Therefore, if policymakers aim to increase the supply of facilities to Industry and Mining, Construction and Housing, and Export and Agriculture, the best combination of banks in terms of the type of ownership, is the combination of different-owned banks with specialized state banks for the creation of a state-owned bank. If the goal is to improve the loan supply to Services and Business sector, the best option is to combine different banks with private banks and create a new private bank.

After choosing the type of bank combination, the following assumptions are tested to answer the second question (Which kind of loan is more affected than others?):

Hypothesis 25: Merger of banks has a more positive effect on the Agriculture and Export loan compared with Services loan.

Hypothesis 26: Merger of banks has a more positive effect on the Agriculture and Export loan compared with Manufacturing and Mining loan.

Hypothesis 27: Merger of banks has a more positive effect on the Agriculture and Export loan compared with Construction and Housing loan.

Hypothesis 28: Merger of banks has a more positive effect on the Services loan compared with Manufacturing and Mining loan.

Hypothesis 29: Merger of banks has a more positive effect on the Services loan compared with Construction and Housing loan.

Hypothesis 30: Merger of banks has a more positive effect on the Manufacturing and Mining loan compared with Construction and Housing loan.

Table 9 indicates the result of the hypothesis test.

Table 9

Equivalent equality test (Types of Loans)

\begin{tabular}{llll}
\hline Hypothesis & T- statistic & Prob & Results \\
\hline Hypothesis (25) & 0.752001 & 0.0000 & The Zero hypothesis is rejected \\
Hypothesis (26) & 0.380092 & 0.0001 & The Zero hypothesis is rejected \\
Hypothesis (27) & 0.540048 & 0.1301 & The zero hypothesis is not rejected \\
Hypothesis (28) & 0.450023 & 0.3112 & The zero hypothesis is not rejected \\
Hypothesis (29) & 0.930958 & 0.5971 & The zero hypothesis is not rejected \\
Hypothesis (30) & 0.341498 & 0.2419 & The zero hypothesis is not rejected \\
\hline
\end{tabular}

As can be seen, bank mergers have a more positive effect on the loan supply to Services and the Business sectors than other sectors of the economy. These sectors are more profitable and more productive than others. Bank mergers also have a more positive effect on the supply of facilities to the 
Housing and Construction sectors than the Industrial and Mining sectors. Since the Housing and Construction sectors are one of the strategic sectors in Iran, the supply of facilities for these sectors is one of the requirements of all banks in Iran.

\section{Conclusion}

The role of banks in financing has made more pronounced the importance of examining the effect of banks' mergers on credit supply. Due to the lack of diversified financial instruments and extensive financial markets in Iran, the Iranian banking network plays the most important role in financing. Banks in Iran are required to provide facilities to various economic sectors such as Agriculture, Export, Industry and Mining, Construction and Housing, Services and Business. To reform the structure of the Iranian banking system, the Iranian central bank wants to merge some banks and create a larger bank. The main goals of this merger are to improve the financial structure, the resources of the target banks, improve the quality of services, and improve the supply of facilities.

Two fundamental questions in this paper are:

Which combination of banks, by the type of ownership, has the most positive effect of the kind of economic sector loan offered? Which kind of loan is more affected than others?

Since mergers in Iran have no long history and access to mergers is not possible, in this paper, a simple combination of the banks 'financial statements has been used to form the merged banks' financial statements. Since the type of ownership and health of banks influence the results of mergers, banks are divided into three groups by type of ownership: commercial state, specialized state, and private banks. So they are divided into two groups by healthy: Healthy and Unhealthy. The CAMELS rating model was used to identify healthy banks. To answer these two questions, design 28 models and have been tested 30 hypotheses.

There have been few studies on the effect of bank mergers on the composition of facilities in foreign studies, and no study has been conducted in Iran, and this is the first study in this field. The results of empirical studies such as Erel (2011), Di Patti and Gobbi (2007) indicate that the composition of facilities granted to different economic sectors changes after integration. The results of this study suggest that the combination of varying ownership banks with private banks and the creation of a new private bank will increase the supply of facilities to the Services and Business sector more than other facilities. In these conditions, the Agricultural and Export sector facilities are 
also reduced. On the other hand, the combination of different ownership banks with state-owned banks and the creation of a new state-owned bank will increase the supply of facilities to Industry and Mining, Housing and Construction more than any others. It reduces the supply of Agricultural facilities in the first period, then rises.

Alternatively, the study of the effect of banks' mergers on the composition of facilities indicates that banks' mergers have a more positive effect on the supply of facilities to the Services and Business sectors than others. Subsequently, the supply of facilities to the Construction and Housing sector is more than the supply of facilities to the Industry and Mining, Agriculture and Export.

The combination of banks based on health also indicates that at least one of the banks involved in the merger process must be healthy to have a positive impact on the supply of facilities. The combination of healthy banks has a more positive impact on the supply of facilities to the Industry and Mining, Construction and Housing sectors compared to others.

Finally, it is suggested that policymakers of the Iranian banking network consider the importance of different economic sectors to achieve the positive effects of banks' mergers on the supply of facilities. At the same time, they better find the type of banks' ownership and health to create a state-owned bank to meet the healthy bank requirements.

\section{References}

Ahrendsen, B. L., Dixon, B. L., \& Luo, B. (2003). The Effects of Bank Mergers on Commercial Bank Agricultural Lending. American Agricultural Economics Association Annual Meeting, Montreal, Canada, July, 27-30.

Avery, R. B., \& Samolyk, K. A. (2004). Bank Consolidation and Small Business Lending: The Role of Community Banks. Journal of Financial Services Research, 25(2-3), P. 291-325.

Baltagi, B. H. (2005). Econometric Analysis of Panel Data. 3rd Edition, New York: John Wiley \& Sons Inc.

Berger, A. N., Rosen, R. J., \& Udell, G. F. (2007). Does Market Size Structure Affect Competition? The Case of Small Business Lending. Journal of Banking \& Finance, 31(1), 11-33.

Berger, A. N., Demirgüç-Kunt, A., Levine, R., \& Haubrich, J. G. (2004). Bank Concentration and Competition: An Evolution in the Making. Journal of Money, Credit and Banking, 36(3).

Di Patti, E. B., \& Gobbi, G. (2007). Winners or Losers? The Effects of Banking Consolidation on Corporate Borrowers. Journal of Finance, 62(2), 669-695. 
Erel, I. (2011). The Effect of Bank Mergers On Loan Prices: Evidence from The United States. Review of Financial Studies, 24(4), 1068-1101.

Farrell, J., \& Shapiro, C. (1990). Horizontal Mergers: An Equilibrium Analysis. American Economic Review, 80, 107-26.

Gilbert, R. A., \& Belongia, M. T. (1988). The Effects of Affliction with Large Bank Holding Companies on Commercial Bank Lending to Agriculture. American Journal of Agricultural Economics, 70(1), 69-78.

Haddad, G. R. K., \& Mohit, S. (2012). Dual Job Holding in Iran's Urban Labor Market: An application of panel data and dual sample selection. Economic Research Journal, 47(3), 85-108.

Hausman, J. A. (1978). Specification Tests in Econometrics. Econometrica: Journal of the Econometric Society, 46(6), 1251-1271.

Kahn, C., Pennacchi, G., \& Sopranzetti, B. (2005). Bank Consolidation and Consumer Loan Interest Rates. The Journal of Business, 78(1), 99-134.

Keeton, W. R. (1996). Do Bank Mergers Reduce Lending to Businesses and Farmers? New Evidence from Tenth District States. Economic Review, Federal Reserve Bank of Kansas City, 81(3), 63-75.

Montoriol-Garriga, J. (2008). Bank Mergers, and Lending Relationships. ECB Working Paper No. 934,

Peek, J., \& Rosengren, E. S. (1998). Bank Consolidation and Small Business Lending: It_s Not Just Bank Size That Matters. Journal of Banking \& Finance, 22(6-8), 799-819.

Prasad, K. V. N., \& Ravinder, G. (2012). A Camel Model Analysis of Nationalized Banks in India. International Journal of Trade and Business, 6(1), 23-33.

Strahan, P. E., \& Weston, J. (1998). Small Business Lending and the Changing Structure of the Banking Industry. Journal of Banking and Finance, 22, 821-845. 


\section{Appendix}

Table 10

(Agriculture + Export Loan) to Total Loan (Healthy-Unhealthy)

\begin{tabular}{|c|c|c|c|}
\hline Kind of Merging and Independent Variable & Healthy - Healthy & Healthy - Unhealthy & $\begin{array}{l}\text { Unhealthy } \\
\text { Unhealthy }\end{array}$ \\
\hline Intercept & \begin{tabular}{|l|}
-2.842576 \\
$(-6.215310)$ \\
{$[0.000]$}
\end{tabular} & \begin{tabular}{|l|}
-2.659398 \\
$(-5.831819)$ \\
{$[0.000]$}
\end{tabular} & \begin{tabular}{|l|}
-2.520873 \\
$(-5.435927)$ \\
{$[0.000]$}
\end{tabular} \\
\hline Merging in Current Period & $\begin{array}{l}0.092145 \\
(0.660343) \\
{[0.5108]} \\
\end{array}$ & $\begin{array}{l}0.159360 \\
(1.116045) \\
{[0.2675]} \\
\end{array}$ & $\begin{array}{l}0108333 \\
(0.730008) \\
{[0.4674]} \\
\end{array}$ \\
\hline One year after merging & \begin{tabular}{|l}
0.119577 \\
$(0.851577)$ \\
{$[0.3968]$}
\end{tabular} & $\begin{array}{l}0.143674 \\
(1.006077) \\
{[0.3172]}\end{array}$ & $\begin{array}{l}0.171976 \\
(1.159072) \\
{[0.2497]} \\
\end{array}$ \\
\hline Two year after merging & $\begin{array}{l}0.050646 \\
(0.488588) \\
{[0.6264]} \\
\end{array}$ & $\begin{array}{l}0.053972 \\
(0.511485) \\
{[0.6103]} \\
\end{array}$ & $\begin{array}{l}0.041709 \\
(0.374874) \\
{[0.7087]} \\
\end{array}$ \\
\hline Three year after merging & $\begin{array}{l}0.244405 \\
(2.647958) \\
{[0.0096]}\end{array}$ & $\begin{array}{l}0.250858 \\
(2.668567) \\
{[0.0091]}\end{array}$ & $\begin{array}{l}0.251612 \\
(2.589782) \\
{[0.0113]}\end{array}$ \\
\hline Non-Performing Loan to Total Loan & \begin{tabular}{|l|}
-0.696963 \\
$(-5.861336)$ \\
{$[0.000]$}
\end{tabular} & $\begin{array}{l}-0.737236 \\
(-6.172132) \\
{[0.000]}\end{array}$ & $\begin{array}{l}-0.707492 \\
(-5.726271) \\
{[0.000]}\end{array}$ \\
\hline Deposit & $\begin{array}{l}0.380508 \\
(3.176196) \\
{[0.0021]} \\
\end{array}$ & $\begin{array}{l}0.326252 \\
(2.706386) \\
{[0.0082]} \\
\end{array}$ & $\begin{array}{l}0.319945 \\
(2.526643) \\
{[0.0134]} \\
\end{array}$ \\
\hline Liquid Assets to Short Term Liabilities & $\begin{array}{l}-0.098911 \\
(-0.566736) \\
{[0.5724]}\end{array}$ & $\begin{array}{l}-0.003827 \\
(-0.022678) \\
{[0.9820]}\end{array}$ & $\begin{array}{l}-0.061784 \\
(-0.331809) \\
{[0.7409]}\end{array}$ \\
\hline Capital Adequacy & \begin{tabular}{|l|}
-0.386309 \\
$(-2.079730)$ \\
{$[0.0405]$}
\end{tabular} & $\begin{array}{l}-0.425089 \\
(-2.200627) \\
{[0.0304]} \\
\end{array}$ & $\begin{array}{l}-0.376939 \\
(-1.912726) \\
{[0.0592]} \\
\end{array}$ \\
\hline R2 & 0.955439 & 0.953958 & 0.953041 \\
\hline R2-Adiusted & 0.939376 & 0.937361 & 0.935710 \\
\hline $\mathrm{D}-\mathrm{W}$ & 1.742289 & 1.751658 & 1.733772 \\
\hline
\end{tabular}


Table 11

(Agriculture + Export Loan) to Total Loan (Ownership)

\begin{tabular}{|c|c|c|c|c|}
\hline $\begin{array}{l}\text { Kind of Merging and Independent } \\
\text { Variable }\end{array}$ & $\begin{array}{l}\text { Commercial } \\
\text { State Bank } \\
\text { Commercial } \\
\text { State Bank } \\
\end{array}$ & $\begin{array}{l}\text { Commercial } \\
\text { State Bank } \\
\text { Commercial } \\
\text { Private Bank }\end{array}$ & $\begin{array}{l}\text { Commercial } \\
\text { Private Bank } \\
\text { Commercial } \\
\text { Private Bank }\end{array}$ & \begin{tabular}{|l|} 
Specialized \\
State Bank \\
Commercial \\
Private Bank
\end{tabular} \\
\hline Intercept & \begin{tabular}{|l|}
-2.553435 \\
$(-5.556957)$ \\
{$[0.000]$}
\end{tabular} & \begin{tabular}{|l|}
-2.727099 \\
$(-5.877796)$ \\
{$[0.000]$}
\end{tabular} & \begin{tabular}{|l|}
-2.373664 \\
$(-5.176430)$ \\
{$[0.000]$}
\end{tabular} & \begin{tabular}{|l|}
-2.718147 \\
$(-5.947683)$ \\
{$[0.000]$}
\end{tabular} \\
\hline Merging in Current Period & \begin{tabular}{|l|l}
0.108258 \\
$(0.755677)$ \\
{$[0.4519]$} \\
\end{tabular} & $\begin{array}{l}0.082792 \\
(0.637453) \\
{[0.5254]} \\
\end{array}$ & $\begin{array}{l}0.059562 \\
(0.418693) \\
{[0.6765]} \\
\end{array}$ & $\begin{array}{l}0.059516 \\
(0.421259) \\
{[0.6746]} \\
\end{array}$ \\
\hline One year after merging & \begin{tabular}{|l}
0.147645 \\
$(1.017642)$ \\
{$[0.3117]$} \\
\end{tabular} & \begin{tabular}{|l}
0.060614 \\
$(0.458742)$ \\
{$[0.6475]$} \\
\end{tabular} & $\begin{array}{l}0.157506 \\
(1.098345) \\
{[0.2751]} \\
\end{array}$ & $\begin{array}{l}0.130675 \\
(0.918494) \\
{[0.3609]} \\
\end{array}$ \\
\hline Two year after merging & $\begin{array}{l}0.047151 \\
(0.439157) \\
{[0.6616]}\end{array}$ & $\begin{array}{l}0.054022 \\
(0.5524120 \\
{[0.5820]}\end{array}$ & $\begin{array}{l}0.059553 \\
(0.559848) \\
{[0.5770]} \\
\end{array}$ & $\begin{array}{l}0.046922 \\
(0.446643) \\
{[0.6563]} \\
\end{array}$ \\
\hline Three year after merging & $\begin{array}{l}0.252890 \\
(2.646340) \\
{[0.0097]} \\
\end{array}$ & $\begin{array}{l}0.184431 \\
(2.122567) \\
{[0.0365]} \\
\end{array}$ & $\begin{array}{l}0.255838 \\
(2.710376) \\
{[0.0081]} \\
\end{array}$ & $\begin{array}{l}0.250507 \\
(2.676006) \\
{[0.0089]} \\
\end{array}$ \\
\hline Non-Performing Loan to Total Loan & \begin{tabular}{|l|}
-0.714688 \\
$(-5.848476)$ \\
{$[0.000]$}
\end{tabular} & \begin{tabular}{|l|}
-0.689585 \\
$(-5.636463)$ \\
{$[0.000]$}
\end{tabular} & \begin{tabular}{|l|}
-0.727400 \\
$(-6.074124)$ \\
{$[0.000]$}
\end{tabular} & \begin{tabular}{|l|}
-0.681977 \\
$(-5.660067)$ \\
{$[0.000]$}
\end{tabular} \\
\hline Deposit & $\begin{array}{l}0.326563 \\
(2.653290) \\
{[0.0095]} \\
\end{array}$ & $\begin{array}{l}0.353643 \\
(2.866070) \\
{[0.0052]} \\
\end{array}$ & $\begin{array}{l}0.278052 \\
(2.280982) \\
{[0.0250]} \\
\end{array}$ & $\begin{array}{l}0.360070 \\
(2.972047) \\
{[0.0038]} \\
\end{array}$ \\
\hline Liquid Assets to Short Term Liabilities & \begin{tabular}{|l|}
-0.008554 \\
$(-0.048705)$ \\
{$[0.9613]$}
\end{tabular} & $\begin{array}{l}-0.171810 \\
(-0.980513) \\
{[0.3294]}\end{array}$ & \begin{tabular}{|l|}
-0.016025 \\
$(-0.092299)$ \\
{$[0.9267]$} \\
\end{tabular} & $\begin{array}{l}-0.081659 \\
(-0.462499) \\
{[0.6449]}\end{array}$ \\
\hline Capital Adequacy & \begin{tabular}{|l|}
-0.339393 \\
$(-1.772937)$ \\
{$[0.0797]$} \\
\end{tabular} & \begin{tabular}{|l|}
-0.401532 \\
$(-2.140530)$ \\
{$[0.0350]$} \\
\end{tabular} & \begin{tabular}{|l|}
-0.321706 \\
$(-1.694539)$ \\
{$[0.0938]$} \\
\end{tabular} & \begin{tabular}{|l|}
-0.359240 \\
$(-1.915475)$ \\
{$[0.0588]$} \\
\end{tabular} \\
\hline $\mathrm{R} 2$ & 0.951813 & 0.954244 & 0.953502 & 0.954253 \\
\hline R2-Adiusted & 0.934643 & 0.938826 & 0.936742 & 0.937762 \\
\hline $\mathrm{D}-\mathrm{W}$ & 1.622668 & 1.719962 & 1.747234 & 1.782433 \\
\hline
\end{tabular}


Table 12

(Service + Business Loan) to Total Loan (Healthy-Unhealthy)

\begin{tabular}{|l|l|l|l|}
\hline Kind of Merging and Independent Variable & $\begin{array}{l}\text { Healthy } \\
\text { Healthy }\end{array}$ & $\begin{array}{l}\text { Healthy } \\
\text { Unhealthy }\end{array}$ & $\begin{array}{l}\text { Unhealthy } \\
\text { Unhealthy }\end{array}$ \\
\hline \multirow{2}{*}{ Intercept } & 0.152594 & 0.143259 & 0.146461 \\
& $(0.777926)$ & $(0.756416)$ & $(0.777460)$ \\
& {$[0.4386]$} & {$[0.4513]$} & {$[0.4389]$} \\
\hline \multirow{2}{*}{ Merging in Current Period } & 0.522345 & 0.502278 & 0.480024 \\
& $(7.223769)$ & $(7.015793)$ & $(6.621322)$ \\
& {$[0.000]$} & {$[0.000]$} & {$[0.000]$} \\
\hline \multirow{3}{*}{ One year after merging } & 0.541183 & 0.545783 & 0.537899 \\
& $(7.531138)$ & $(7.706091)$ & $(7.492346)$ \\
\hline \multirow{3}{*}{ Two year after merging } & {$[0.000]$} & {$[0.000]$} & {$[0.000]$} \\
\hline \multirow{2}{*}{ Three year after merging } & -0.509415 & -0.508514 & -0.507168 \\
& $(-9.628797)$ & $(-9.749167)$ & $(-9.506770)$ \\
\hline \multirow{2}{*}{ Non-Performing Loan to Total Loan } & {$[0.000]$} & {$[0.000]$} & {$[0.000]$} \\
\hline \multirow{2}{*}{ Deposit } & 0.071850 & 0.075843 & 0.071972 \\
& $(1.490638)$ & $(1.594169)$ & $(1.500868)$ \\
\hline Liquid Assets to Short Term Liabilities & {$[0.1394]$} & {$[0.1143]$} & {$[0.1368]$} \\
\hline & -0.124980 & -0.126528 & -0.132040 \\
& $(-2.214099)$ & $(-2.307191)$ & $(-2.404098)$ \\
\hline Capital Adequacy & {$[0.0292]$} & {$[0.0232]$} & {$[0.0182]$} \\
\hline R2 & 0.179713 & 0.175254 & 0.183397 \\
\hline R2-Adiusted & $(3.966145)$ & $(3.989349)$ & $(4.162976)$ \\
\hline D-W & {$[0.0001]$} & {$[0.0001]$} & {$[0.0001]$} \\
\hline & -0.297652 & -0.312050 & -0.335224 \\
& $(-3.422212)$ & $(-3.722359)$ & $(-3.883261)$ \\
\hline & {$[0.0009]$} & {$[0.0003]$} & {$[0.0002]$} \\
\hline & -0.045118 & -0.077421 & -0.087031 \\
& $(-0.470900)$ & $(-0.802675)$ & $(-0.908661)$ \\
\hline & {$[0.6388]$} & {$[0.4242]$} & {$[0.3659]$} \\
\hline & 0.956572 & 0.957900 & 0.956882 \\
\hline & 0.941326 & 0.943121 & 0.941415 \\
\hline & 1.915033 & 1.743200 & 1.732587 \\
\hline
\end{tabular}


Table 13

(Service + Business Loan) to Total Loan (Ownership)

\begin{tabular}{|c|c|c|c|c|}
\hline $\begin{array}{l}\text { Kind of Merging and Independent } \\
\text { Variable }\end{array}$ & $\begin{array}{l}\text { Commercial } \\
\text { State Bank } \\
\text { Commercial } \\
\text { State Bank } \\
\end{array}$ & $\begin{array}{l}\text { Commercial } \\
\text { State Bank } \\
\text { Commercial } \\
\text { Private Bank }\end{array}$ & $\begin{array}{l}\text { Commercial } \\
\text { Private Bank } \\
\text { Commercial } \\
\text { Private Bank }\end{array}$ & $\begin{array}{l}\text { Specialized } \\
\text { State Bank } \\
\text { Commercial } \\
\text { Private Bank }\end{array}$ \\
\hline Intercept & \begin{tabular}{|l|}
0.151564 \\
$(0.798023)$ \\
{$[0.4263]$}
\end{tabular} & \begin{tabular}{|l|}
0.152789 \\
$(0.775054)$ \\
{$[0.4401]$}
\end{tabular} & \begin{tabular}{|l|}
0.133524 \\
$(0.695891)$ \\
{$[0.4882]$} \\
\end{tabular} & \begin{tabular}{|l|}
0.139092 \\
$(0.714084)$ \\
{$[0.4769]$} \\
\end{tabular} \\
\hline Merging in Current Period & $\begin{array}{l}0.520695 \\
(7.316027) \\
{[0.000]} \\
\end{array}$ & \begin{tabular}{|l|}
0.456605 \\
$(6.830248)$ \\
{$[0.000]$} \\
\end{tabular} & $\begin{array}{l}0.512524 \\
(7.114413) \\
{[0.000]} \\
\end{array}$ & \begin{tabular}{|l|}
.520159 \\
$(7.194501)$ \\
{$[0.000]$} \\
\end{tabular} \\
\hline One year after merging & $\begin{array}{l}0.539987 \\
(7.566816) \\
{[0.000]}\end{array}$ & $\begin{array}{l}0.499095 \\
(7.454993) \\
{[0.000]}\end{array}$ & $\begin{array}{l}0.540403 \\
(7.520582) \\
{[0.000]}\end{array}$ & $\begin{array}{l}0.540883 \\
(7.519000) \\
{[0.000]}\end{array}$ \\
\hline Two year after merging & $\begin{array}{l}0.508391 \\
(9.671975) \\
{[0.000]}\end{array}$ & $\begin{array}{l}0.466028 \\
(9.434741) \\
{[0.000]}\end{array}$ & $\begin{array}{l}0.507233 \\
(9.561259) \\
{[0.000]}\end{array}$ & $\begin{array}{l}0.508456 \\
(9.605828) \\
{[0.000]}\end{array}$ \\
\hline Three year after merging & $\begin{array}{l}0.070566 \\
(1.472270) \\
{[0.1443]}\end{array}$ & $\begin{array}{l}0.050224 \\
(1.115176) \\
{[0.2674]}\end{array}$ & $\begin{array}{l}0.071569 \\
(1.483551) \\
{[0.1413]}\end{array}$ & $\begin{array}{l}0.072191 \\
(1.495233) \\
{[0.1382]}\end{array}$ \\
\hline Non-Performing Loan to Total Loan & $\begin{array}{l}-0.116213 \\
(-2.093205) \\
{[0.0390]}\end{array}$ & $\begin{array}{l}-0.111348 \\
(-1.946533) \\
{[0.0544]}\end{array}$ & $\begin{array}{l}-0.120031 \\
(-2.160304) \\
{[0.0333]}\end{array}$ & $\begin{array}{l}-0.121118 \\
(-2.142732) \\
{[0.0347]}\end{array}$ \\
\hline Deposit & $\begin{array}{l}0.176915 \\
(3.990618) \\
{[0.0001]} \\
\end{array}$ & $\begin{array}{l}0.179820 \\
(3.918068) \\
{[0.0002]} \\
\end{array}$ & $\begin{array}{l}0.180190 \\
(4.035455) \\
{[0.0001]} \\
\end{array}$ & \begin{tabular}{|l|}
0.180497 \\
$(3.982389)$ \\
{$[0.0001]$} \\
\end{tabular} \\
\hline Liquid Assets to Short Term Liabilities & $\begin{array}{l}-0.301446 \\
(-3.578695) \\
{[0.0005]}\end{array}$ & $\begin{array}{l}-0.316406 \\
(-3.655170) \\
{[0.0004]}\end{array}$ & $\begin{array}{l}-0.297455 \\
(-3.506922) \\
{[0.0007]}\end{array}$ & $\begin{array}{l}-0.295128 \\
(-3.393542) \\
{[0.0010]}\end{array}$ \\
\hline Capital Adequacy & $\begin{array}{l}-0.047450 \\
(-0.500626) \\
{[0.6178]}\end{array}$ & $\begin{array}{l}-0.049747 \\
(-0.520372) \\
{[0.6040]}\end{array}$ & $\begin{array}{l}-0.052634 \\
(-0.548976) \\
{[0.5843]}\end{array}$ & $\begin{array}{l}-0.048693 \\
(-0.509338) \\
{[0.6117]}\end{array}$ \\
\hline R2 & 0.956644 & 0.952752 & 0.956579 & 0.956461 \\
\hline R2-Adiusted & 0.941584 & 0.937160 & 0.941335 & 0.941176 \\
\hline $\mathrm{D}-\mathrm{W}$ & 1.701947 & 1.713215 & 1.754952 & 1.793713 \\
\hline
\end{tabular}




\section{Table 14}

Industry and Mining Loan to Total Loan (Healthy-Unhealthy)

\begin{tabular}{|l|l|l|l|}
\hline Kind of Merging and Independent Variable & $\begin{array}{l}\text { Healthy } \\
\text { Healthy }\end{array}$ & $-\begin{array}{l}\text { Healthy } \\
\text { Unhealthy }\end{array}$ & $\begin{array}{l}\text { Unhealthy } \\
\text { Unhealthy }\end{array}$ \\
\hline \multirow{2}{*}{ Intercept } & 0.248399 & -0.116504 & -0.140311 \\
& $(-0.667422)$ & $(-0.306801)$ & $(-0.368973)$ \\
\hline \multirow{2}{*}{ Merging in Current Period } & {$[0.5062]$} & {$[0.7597]$} & {$[0.7130]$} \\
\hline \multirow{3}{*}{ One year after merging } & 0.073419 & 0.130111 & 0.157574 \\
& $(0.618043)$ & $(1.054114)$ & $(1.244924)$ \\
\hline \multirow{3}{*}{ Two year after merging } & {$[0.5381]$} & {$[0.2946]$} & {$[0.2164]$} \\
\hline & 0.032394 & 0.030419 & 0.045180 \\
& $(0.277850)$ & $(0.251862)$ & $(0.364703)$ \\
\hline Three year after merging & {$[0.7818]$} & {$[0.8017]$} & {$[0.7162]$} \\
\hline \multirow{2}{*}{ Non-Performing Loan to Total Loan } & 0.040349 & 0.045556 & 0.056862 \\
& $(0.469494)$ & $(0.511855)$ & $(0.616629)$ \\
\hline \multirow{2}{*}{ Deposit } & {$[0.6398]$} & {$[0.6100]$} & {$[0.5390]$} \\
\hline Liquid Assets to Short Term Liabilities & 0.077919 & 0.087208 & 0.095680 \\
& $(1.002457)$ & $(1.084269)$ & $(1.164705)$ \\
\hline Capital Adequacy & {$[0.3188]$} & {$[0.2811]$} & {$[0.2472]$} \\
\hline R2 & -0.068250 & -0.109025 & -0.107462 \\
& $(-0.666460)$ & $(-1.040078)$ & $(-1.012470)$ \\
\hline R2-Adiusted & {$[0.5068]$} & {$[0.3010]$} & {$[0.3140]$} \\
\hline D-W & 0.220285 & 0.175128 & 0.183690 \\
& $(2.605990)$ & $(2.038384)$ & $(2.104612)$ \\
\hline & {$[0.0107]$} & {$[0.0444]$} & {$[0.0381]$} \\
\hline & -0.299773 & -0.372498 & -0.384064 \\
& $(-2.114387)$ & $(-2.569366)$ & $(-2.0542806)$ \\
\hline & {$[0.0372]$} & {$[0.0118]$} & {$[0.0127]$} \\
\hline & -0.149719 & -0.129093 & -0.119374 \\
& $(-0.951217)$ & $(-0.775144)$ & $(-0.713990)$ \\
\hline & {$[0.3440]$} & {$[0.4402]$} & {$[0.4771]$} \\
\hline & 0.952035 & 0.950527 & 0.950100 \\
\hline & 0.935351 & 0.933319 & 0.932357 \\
\hline & 1.838069 & 1.791609 & 1.795305 \\
\hline
\end{tabular}


Table 15

Industry and Mining Loan to Total Loan (Ownership)

\begin{tabular}{|c|c|c|c|c|}
\hline Kind of Merging and Independent Variable & $\begin{array}{l}\text { Commercial } \\
\text { State Bank } \\
\text { Commercial } \\
\text { State Bank }\end{array}$ & $\begin{array}{l}\text { Commercial } \\
\text { State Bank } \\
\text { Commercial } \\
\text { Private Bank }\end{array}$ & $\begin{array}{l}\text { Commercial } \\
\text { Private Bank } \\
\text { Commercial } \\
\text { Private Bank }\end{array}$ & $\begin{array}{l}\text { Specialized } \\
\text { State Bank } \\
\text { Commercial } \\
\text { Private Bank }\end{array}$ \\
\hline Intercept & \begin{tabular}{|l|}
-0.126449 \\
$(-0.335425)$ \\
{$[0.7381]$}
\end{tabular} & $\begin{array}{l}-0.282084 \\
(-0.769765) \\
{[0.4433]}\end{array}$ & \begin{tabular}{|l}
-0.104922 \\
$(-0.276189)$ \\
{$[0.7830]$}
\end{tabular} & \begin{tabular}{|l}
-0.291945 \\
$(-0.793976)$ \\
{$[0.4293]$}
\end{tabular} \\
\hline Merging in Current Period & $\begin{array}{l}0.126103 \\
(1.025827) \\
{[0.3077]}\end{array}$ & $\begin{array}{l}0.052644 \\
(0.487863) \\
{[0.6268]}\end{array}$ & $\begin{array}{l}0.117063 \\
(0.953988) \\
{[0.3426]}\end{array}$ & $\begin{array}{l}0.085743 \\
(0.720943) \\
{[0.4728]}\end{array}$ \\
\hline One year after merging & $\begin{array}{l}0.032764 \\
(0.270256) \\
{[0.7876]}\end{array}$ & $\begin{array}{l}0.005047 \\
(0.047135) \\
{[0.9625]}\end{array}$ & $\begin{array}{l}0.033010 \\
(0.272754) \\
{[0.7857]}\end{array}$ & $\begin{array}{l}0.035746 \\
(0.305966) \\
{[0.7603]}\end{array}$ \\
\hline Two year after merging & $\begin{array}{l}0.045486 \\
(0.509238) \\
{[0.6118]}\end{array}$ & $\begin{array}{l}0.022935 \\
(0.290669) \\
{[0.7719]}\end{array}$ & $\begin{array}{l}0.04386 \\
(0.488611) \\
{[0.6263]}\end{array}$ & $\begin{array}{l}0.041691 \\
(0.484232) \\
{[0.6294]}\end{array}$ \\
\hline Three year after merging & $\begin{array}{l}0.089068 \\
(1.103326) \\
{[0.2728]}\end{array}$ & $\begin{array}{l}0.045335 \\
(0.628486) \\
{[0.5312]}\end{array}$ & $\begin{array}{l}0.089799 \\
(1.114539) \\
{[0.2680]}\end{array}$ & $\begin{array}{l}0.079706 \\
(1.022402) \\
{[0.3093]}\end{array}$ \\
\hline Non-Performing Loan to Total Loan & $\begin{array}{l}-0.113130 \\
(-1.063133) \\
{[0.2905]}\end{array}$ & $\begin{array}{l}-0.069497 \\
(-0.682631) \\
{[0.4965]}\end{array}$ & $\begin{array}{l}-0.112706 \\
(-1.075849) \\
{[0.2848]}\end{array}$ & \begin{tabular}{|l|}
-0.07278 \\
$(-0.714980)$ \\
{$[0.4764]$}
\end{tabular} \\
\hline Deposit & $\begin{array}{l}0.180208 \\
(2.082503) \\
{[0.0401]} \\
\end{array}$ & $\begin{array}{l}0.227531 \\
(2.699399) \\
{[0.0082]} \\
\end{array}$ & $\begin{array}{l}0.177123 \\
(2.047595) \\
{[0.0435]} \\
\end{array}$ & \begin{tabular}{|l|}
0.226427 \\
$(2.681027)$ \\
{$[0.0087]$} \\
\end{tabular} \\
\hline Liquid Assets to Short Term Liabilities & $\begin{array}{l}-0.360308 \\
(-2.485205) \\
{[0.0148]}\end{array}$ & $\begin{array}{l}-0.295870 \\
(-2.119772) \\
{[0.0366]}\end{array}$ & $\begin{array}{l}-0.364458 \\
(-2.515748) \\
{[0.0136]}\end{array}$ & \begin{tabular}{|l|}
-0.293893 \\
$(-2.072760)$ \\
{$[0.0410]$}
\end{tabular} \\
\hline Capital Adequacy & $\begin{array}{l}-0.153602 \\
(-0.936653) \\
{[0.3514]}\end{array}$ & $\begin{array}{l}-0.145029 \\
(-0.932993) \\
{[0.3532]}\end{array}$ & $\begin{array}{l}-0.155608 \\
(-0.951875) \\
{[0.3437]}\end{array}$ & $\begin{array}{l}-0.138703 \\
(-0.883422) \\
{[0.3793]}\end{array}$ \\
\hline $\mathrm{R} 2$ & 0.950130 & 0.950625 & 0.950312 & 0.951833 \\
\hline R2-Adiusted & 0.932784 & 0.934166 & 0.933030 & 0.935079 \\
\hline $\mathrm{D}-\mathrm{W}$ & 1.773171 & 1.821113 & 1.774059 & 1.828260 \\
\hline
\end{tabular}


Table 16

Construction and Housing Loan to Total Loan (Healthy-Unhealthy)

\begin{tabular}{|l|l|l|l|}
\hline Kind of Merging and Independent Variable & $\begin{array}{l}\text { Healthy } \\
\text { Healthy }\end{array}$ & $-\begin{array}{l}\text { Healthy } \\
\text { Unhealthy }\end{array}$ & $-\begin{array}{l}\text { Unhealthy } \\
\text { Unhealthy }\end{array}$ \\
\hline \multirow{2}{*}{ Intercept } & 1.295365 & 1.301718 & 1.374477 \\
& $(5.226411)$ & $(5.357608)$ & $(5.840231)$ \\
& {$[0.000]$} & {$[0.000]$} & {$[0.000]$} \\
\hline \multirow{2}{*}{ Merging in Current Period } & 0.092597 & 0.095830 & 0.091069 \\
& $(1.168345)$ & $(1.205067)$ & $(1.157770)$ \\
\hline \multirow{3}{*}{ One year after merging } & {$[0.2458]$} & {$[0.2314]$} & {$[0.2502]$} \\
\hline \multirow{3}{*}{ Two year after merging } & 0.153986 & 0.154240 & 0.144622 \\
& $(1.918481)$ & $(1.924665)$ & $(1.822920)$ \\
\hline \multirow{2}{*}{ Three year after merging } & {$[0.0583]$} & {$[0.0575]$} & {$[0.0718]$} \\
\hline \multirow{2}{*}{ Non-Performing Loan to Total Loan } & 0.141340 & 0.141495 & 0.139283 \\
& $(2.455945)$ & $(2.460789)$ & $(2.420167)$ \\
\hline \multirow{2}{*}{ Deposit } & {$[0.0160]$} & {$[0.0158]$} & {$[0.0176]$} \\
\hline Liquid Assets to Short Term Liabilities & 0.084839 & 0.085842 & 0.098898 \\
& $(1.606361)$ & $(1.625076)$ & $(1.904455)$ \\
\hline \multirow{2}{*}{ Capital Adequacy } & {$[0.0118]$} & {$[0.0077]$} & {$[0.0602]$} \\
\hline R2 & -0.119524 & -0.115519 & -0.139005 \\
& $(-1.789158)$ & $(-1.748943)$ & $(-2.152619)$ \\
\hline R2-Adiusted & {$[0.0770]$} & {$[0.0838]$} & {$[0.0341]$} \\
\hline D-W & 0.113794 & 0.115638 & 0.106393 \\
& $(2.123116)$ & $(2.195062)$ & $(2.068770)$ \\
\hline & {$[0.0366]$} & {$[0.0308]$} & {$[0.0416]$} \\
\hline & -0.340946 & -0.343472 & -0.406490 \\
& $(-3.598364)$ & $(-3.715110)$ & $(-4.361501)$ \\
\hline & {$[0.0005]$} & {$[0.0004]$} & {$[0.000]$} \\
\hline & -0.259427 & -0.271223 & -0.280938 \\
& $(-2.514031)$ & $(-2.579792)$ & $(-2.758421)$ \\
\hline & {$[0.0138]$} & {$[0.0115]$} & {$[0.0071]$} \\
\hline & 0.9751198 & 0.975627 & 0.977268 \\
\hline & 0.966179 & 0.966765 & 0.968810 \\
\hline & 1.734345 & 1.603660 & 1.942576 \\
\hline
\end{tabular}


Table 17

Construction and Housing Loan to Total Loan (Ownership)

\begin{tabular}{|c|c|c|c|c|}
\hline $\begin{array}{l}\text { Kind of Merging and Independent } \\
\text { Variable }\end{array}$ & \begin{tabular}{|l} 
Commercial \\
State Bank \\
Commercial \\
State Bank \\
\end{tabular} & \begin{tabular}{|l|} 
Commercial \\
State Bank \\
Commercial \\
Private Bank \\
\end{tabular} & \begin{tabular}{|l} 
Commercial \\
Private Bank \\
Commercial \\
Private Bank \\
\end{tabular} & \begin{tabular}{|l|} 
Specialized \\
State Bank \\
Commercial \\
Private Bank \\
\end{tabular} \\
\hline Intercept & \begin{tabular}{|l}
1.289883 \\
$(5.435843)$ \\
{$[0.000]$}
\end{tabular} & \begin{tabular}{|l}
1.166861 \\
$(4.588613)$ \\
{$[0.000]$}
\end{tabular} & \begin{tabular}{|l|}
1.297579 \\
$(5.359579)$ \\
{$[0.000]$}
\end{tabular} & \begin{tabular}{|l|}
1.309522 \\
$(5.367863)$ \\
{$[0.000]$}
\end{tabular} \\
\hline Merging in Current Period & \begin{tabular}{|l|}
-0.082134 \\
$(-1.061090)$ \\
{$[0.2915]$} \\
\end{tabular} & \begin{tabular}{|l|}
-0.075378 \\
$(-1.006098)$ \\
{$[0.3170]$} \\
\end{tabular} & $\begin{array}{l}-0.087058 \\
(-1.105837) \\
{[0.2718]} \\
\end{array}$ & $\begin{array}{l}-0.102231 \\
(-1.295258) \\
{[0.1986]} \\
\end{array}$ \\
\hline One year after merging & $\begin{array}{l}0.150662 \\
(1.904550) \\
{[0.0601]}\end{array}$ & $\begin{array}{l}0.198853 \\
(2.596685) \\
{[0.0109]} \\
\end{array}$ & $\begin{array}{l}0.152571 \\
(1.907871) \\
{[0.0597]}\end{array}$ & $\begin{array}{l}0.151843 \\
(1.897400) \\
{[0.0611]}\end{array}$ \\
\hline Two year after merging & $\begin{array}{l}0.141890 \\
(2.497000) \\
{[0.0144]}\end{array}$ & $\begin{array}{l}0.137393 \\
(2.493512) \\
{[0.0144]} \\
\end{array}$ & $\begin{array}{l}0.144281 \\
(2.506542) \\
{[0.0140]}\end{array}$ & $\begin{array}{l}0.141765 \\
(2.470121) \\
{[0.0154]} \\
\end{array}$ \\
\hline Three year after merging & \begin{tabular}{|l|}
0.082854 \\
$(1.589124)$ \\
{$[0.0156]$} \\
\end{tabular} & $\begin{array}{l}0.120336 \\
(2.381303) \\
{[0.0193]} \\
\end{array}$ & $\begin{array}{l}0.084542 \\
(1.604588) \\
{[0.0122]} \\
\end{array}$ & $\begin{array}{l}0.082840 \\
(1.571727) \\
{[0.0196]} \\
\end{array}$ \\
\hline Non-Performing Loan to Total Loan & \begin{tabular}{|l|}
-0.126303 \\
$(-1.935656)$ \\
{$[0.0561]$}
\end{tabular} & \begin{tabular}{|l|}
-0.120899 \\
$(-1.745790)$ \\
{$[0.0841]$} \\
\end{tabular} & \begin{tabular}{|l|}
-0.118763 \\
$(-1.808234)$ \\
{$[0.0740]$}
\end{tabular} & \begin{tabular}{|l|}
-0.118306 \\
$(-1.781876)$ \\
{$[0.0782]$}
\end{tabular} \\
\hline Deposit & \begin{tabular}{|l|}
0.112636 \\
$(2.166815)$ \\
{$[0.0329]$} \\
\end{tabular} & \begin{tabular}{|l|}
0.097080 \\
$(1.744837)$ \\
{$[0.0843]$} \\
\end{tabular} & \begin{tabular}{|l|}
0.114904 \\
$(2.179407)$ \\
{$[0.0320]$} \\
\end{tabular} & \begin{tabular}{|l}
0.116502 \\
$(2.186325)$ \\
{$[0.0314]$} \\
\end{tabular} \\
\hline Liquid Assets to Short Term Liabilities & \begin{tabular}{|l|}
-0.344685 \\
$(-3.790509)$ \\
{$[0.0003]$}
\end{tabular} & \begin{tabular}{|l|}
-0.295093 \\
$(-3.049784)$ \\
{$[0.0030]$}
\end{tabular} & \begin{tabular}{|l|}
-0.348824 \\
$(-3.793616)$ \\
{$[0.0003]$}
\end{tabular} & \begin{tabular}{|l|}
-0.342028 \\
$(-3.625883)$ \\
{$[0.0005]$}
\end{tabular} \\
\hline Capital Adequacy & $\begin{array}{l}-0.260811 \\
(-2.575965) \\
{[0.0116]} \\
\end{array}$ & \begin{tabular}{|l|}
-0.221121 \\
$(-2.091827)$ \\
{$[0.0392]$} \\
\end{tabular} & \begin{tabular}{|l|}
-0.261253 \\
$(-2.538475)$ \\
{$[0.0129]$} \\
\end{tabular} & \begin{tabular}{|l|}
-0.264539 \\
$(-2.581877)$ \\
{$[0.0115]$} \\
\end{tabular} \\
\hline $\mathrm{R} 2$ & 0.975931 & 0.971752 & 0.975705 & 0.975321 \\
\hline R2-Adiusted & 0.967277 & 0.96 & 0.966871 & 0.966347 \\
\hline $\mathrm{D}-\mathrm{W}$ & 1.821804 & 1.905221 & 1.794622 & 1.863544 \\
\hline
\end{tabular}

